\title{
The Effect of Animation-Based Worked Examples Supported with Augmented Reality on the Academic Achievement, Attitude and Motivation of Students towards Learning Programming
}

\author{
Hakan Cevahir* \\ Department of Computer and Instructional Technologies, Çanakkale Onsekiz Mart \\ University, Çanakkale, Turkey; ORCID: 0000-0002-7909-6708 \\ Muzaffer Özdemir \\ Department of Computer and Instructional Technologies, Çanakkale Onsekiz Mart \\ University, Çanakkale, Turkey; ORCID: 0000-0002-5490-238X
}

Meltem Huri Baturay

Center for Teaching and Learning, Attlum University, Ankara, Turkey; ORCID: 0000-0003-2402-6275

Article history

Received:

03.03.2021

Received in revised form:

25.10.2021

Accepted:

18.11.2021

Key words:

Augmented reality,

Animation-based education,

Programming education,

Worked examples
This study examines the effect of using animation-based worked examples (ARAWEs) that are prepared using Augmented Reality (AR) technology instead of using traditional paper-based worked examples (TWEs) on the achievement, motivation, and attitude of high school students during their programming education. The research was designed through the "Nonequivalent Control Group Model", one of the quasiexperimental models. The participants consisted of second year students $(\mathrm{N}=94)$ who were taking the "Basics of Programming" course in the Department of Information Technologies a vocational and technical Anatolian high school in Turkey. An achievement test was applied to the participants as pre-test and final test. Motivation of the students was measured by means of the "Instructional Materials Motivation Survey" developed by Kutu and Sözbilir (2011), and participant attitudes towards using AR was measured by means of the "AR Attitude Scale" developed by Küçük, Yılmaz, Baydaş and Göktaş (2014). According to the results, both the achievement and motivation levels of the students studying on ARAWEs increased significantly compared to those studying on TWEs. There was a high level of correlation between the final test scores and the attitude levels of the students studying on ARAWEs. Considering that instructional materials containing animation-based worked examples prepared using AR technology increase students' interest and motivation in the subject, their use in lessons that include teaching problem solving skills, such as mathematics, physics, and chemistry, can be implemented in future studies. 


\section{Introduction}

\section{Animation-Based Teaching}

Rieber and Kini (1991) describe animation as the presentation of images on a computer screen, following consecutively and quickly. Weiss, Knowlton and Morrison (2002) indicate that five features of animation help learning in terms of: (1) making teaching attractive, (2) attracting attention, (3) motivating students, (4) presenting information, and (5) giving explanations. Animation aims to visualize the subject taught and to create a mental model of the subject in the audience (Höffler \& Leutner, 2007). Some research studies have been conducted investigating the effect of animation on students' learning (Betrancourt \& Tversky, 2000; Hegarty et al., 2003; Moreno \& Mayer, 2007; Tversky et al., 2002). These studies examined the effects of animation on students' participation levels and their mental learning processes and investigated the instructional effectiveness of animated and non-animated teaching materials on learning outcomes.

Höffler and Leutner (2007) reported some studies indicating how animation-supported teaching affects the students' learning outcomes positively compared to teaching with still images (Park \& Gittelman, 1992; Thompson \& Riding, 1990), while other studies indicated the opposite (Morrison \& Tversky, 2001; Rieber \& Hannafin, 1988; Rieber, 1989). Chiou et al. (2015) conducted an experimental study and found that instructional material enriched with animation together with multi-dimensional concept maps was better than multi-dimensional concept maps alone with respect to students' achievement, satisfaction, and retention. In the study of Luzón and Letón (2015), they suggest that the use of animation in instructional materials facilitates the cognitive processes, such as in selecting information, thus it promotes the students' learning ability. Berney and Betrancourt (2016) in their meta-analysis found that animation-based teaching materials had a positive effect on learning compared to materials containing still pictures. Daşdemir and Doymuş (2016) examined the effect of animation-based teaching materials on academic achievement, retention in achievement, and the scientific process skills development of students in science and technology lessons; it was found that these materials had a positive effect on these constructs. In a study in which student views on the use of animation in science lessons were examined, a positive and moderate relationship was found between students' use of animation and their attitude towards technology (Önal \& Söndür, 2017). In another study, conducted by Rosen (2009), it was reported that animation-based content significantly and positively affects students' knowledge transfer and motivation towards science and technology lessons.

However, other studies reported that the educational use of animation did not affect learning positively or that the effect was limited. To exemplify, in an experimental study carried out Catrambone and Seay (2002) with 99 undergraduate students, the effect of animation on increasing the problem-solving performance for computer algorithms was examined. This study concluded that animation-enriched teaching materials did not significantly affect learning positively, and furthermore was found to support learning only moderately. In their study, Stebner, et al. (2017) reported that animation visualizes the subject more prominently compared to text-based teaching material, but it does not exert a significant effect on learning. Adesope and Nesbit (2013) compared the effect of animation-based concept maps with paper-based concept maps on learning and found no significant difference between the two learning materials. 


\section{Worked Examples}

The "worked example" is a method that guides students by steps to the solution of a problem that was previously solved by a teacher or an expert with schematic drawings. It enables students to use the same methods to reach a solution (Schunk, 2011), and it improves students' problem-solving skills (Crippen \& Earl, 2007). The worked examples allow students to conceive a problem and to apply their own strategies to solve this problem on their own, thereby helping them strengthen their sense of self-efficacy for achievement (Schunk, 1991). At the same time, we can say that worked examples are more useful for students who are in the first stage of skill development rather than those trying to improve their skills (Schunk, 2011).

In the current study, the worked examples are presented to students with Augmented Reality technology, unlike the traditional way, as today the rapidly emerging use of this technology in learning environments is regarded as a crucial element by many researchers in increasing learner's interest and motivation.

\section{Teaching Programming}

Programming, which is the basis of today's technology and is considered to make an important contribution to the processing of information, has been included in the instructional curriculum of many countries (Ministry of Development, 2015; Sayın \& Seferoğlu, 2016). Programming includes many complex processes such as writing, testing, and troubleshooting (Fesakis \& Serafeim, 2009; Sobrino et al., 2020), and is considered a skill where learning and producing results is difficult (Cevahir \& Özdemir, 2017; Lahtinen, Ala-Mutka, \& Hannu-Matt, 2005; Saygıner \& Tüzün, 2017). In addition, teaching programming is considered to significantly contribute to logical reasoning, which requires higher-level thinking skills such as problem solving, critical thinking, analytical thinking, and creativity (Sayın \& Seferoğlu, 2016; Yıldız, Çiftçi \& Karal, 2017).

Teaching programming is a challenging process from the point of view of the teacher and learner (Helminen \& Malmi, 2010). In many cases, due to the teaching methods preferred by the teacher, students may experience several perceptual problems while learning programming (Erümit et al., 2018). Therefore, researchers have developed many innovative methods to support teaching programming and have tested the effectiveness of these methods (Kantaria et al., 2020; Malik et al., 2020; Nouri et al., 2019, Nordin, 2021, Van Merrienboer \& Paas, 1990). A study conducted by Kantaria et al. (2020) developed a learning methodology for teaching Phyton language, one of the programming languages, and compared it with traditional learning methods in terms of learning performance. They concluded that the methodology they applied improved Phyton programming learning performance by $10-15 \%$, compared to traditional methods.

Nordin (2021) examined the effectiveness of Java programming language for online teaching and found that achievement rates were similar to traditional teaching methods. Malik et al. (2020) compared the development of problem-solving skills of novice programmers using three different learning methods (e-learning, m-learning, and game-based learning). They reported that all of these three methods contributed positively to the development of algorithmic thinking skills in almost equal proportions. As can be seen, in most of the studies carried out to support teaching programming, methods such as e-learning, m-learning or game-based learning have been employed.

Besides this, there are also studies that used the animation-based teaching method in teaching 
programming (Jawad et al., 2018; Matsuma \& Shindo, 2001; Rudder et al., 2007; Végh, 2016). To sum up, these studies have indicated that animation-based teaching methods have a positive effect on teaching programming.

In addition, it can be said that studies on the use of worked examples in teaching programming are limited (Abdul-Rahman \& Boulay, 2014; Van Merrienboer \& Paas, 1990; Zhi et al., 2019a; Zhi et al., 2019b). These studies stated that use of worked examples in teaching programming contributed positively to the students' learning.

\section{Use of Augmented Reality in Education}

Augmented Reality (AR) enables the integration of 3D virtual objects into the real world simultaneously (Azuma, 1997). AR technology aims to change people's interaction and experience with the real world by enriching the context with virtual objects including images such as pictures, texts and animations. AR technology enabling the integration of real world and virtual objects can be used on desktop, laptop, mobile and tablet computers as well as monitored through head mounted displays (Kirner, Reis \& Kirner, 2012). It can be assumed that the capabilities of AR will be one of the most fascinating technologies used in education in the near future.

There are many studies that state the positive effects of AR technology use in education, such as its effect on: (a) students' problem-solving skills in maths and science (Hodhod et al., 2014; Lin, et al., 2013), (b) students' perceived ease of use and enjoyment (Wojciechowski \& Cellary, 2013), (c) the achievement and motivation of students (Ersoy, Duman, \& Öncü, 2016; Ibáñez et al., 2014), and (d) flow experience in an activity (Ibáñez et al., 2014). In the light of these studies, it can be said that teaching materials and environments containing AR technology contribute positively to students' learning. This could have stemmed from the intense interest of students towards AR, which positively affects their motivation and increases their desire to learn.

As can be seen from the research studies, AR technology provides some advantageous features in the context of traditional teaching by enriching it; it presents an enriched learning experience; it helps students to focus on the subject by making it more attractive; it increases the motivation of learners; it helps to concretize abstract concepts in the students' minds; it requires students to utilise their higher order thinking skills; and it facilitates students' remembering of learnt items (Abdüsselam, 2014; Taşkıran, Koral, \& Bozkurt, 2015; Uluyol \& Eryılmaz, 2014). However, as AR's ability to combine physical and virtual learning experiences increase, there is a need for strategies that help teachers how to teach with augmented reality effectively; design principles on how to design AR instructional materials effectively; and give guidance for students on how to use AR instructional materials effectively in their learning.

\section{Motivation}

Motivation is considered as an important factor that creates a triggering and driving effect on the individual in the emergence of a behaviour and completing a learning process (Bacanl1, 2003; Morgan, 2005). Fidan (1997) defines motivation as a state of empowerment that leads individuals to do a certain activity by contributing cognitively, affectively, and psychologically. According to Akbaba (2006), motivation is one of the most prominent constructs of the teaching process. Also, according to Freedman (1997), motivation plays a large role in a student's achievement. 
Based on its importance in educational environments, motivation is an important phenomenon which has two dimensions, internal and external (Akbaba, 2006). Intrinsic motivation is the result of affective processes that direct the individual to perform a behaviour. Intrinsic motivation is defined as feeling the need to learn and a sense of achievement (Ryan \& Deci, 2000). Intrinsic motivation is the result of affective processes that direct the individual to a behaviour (Collins \& Amabile, 2007). Extrinsic motivation, on the other hand, is the motivation that emerges with effects such as avoidance of punishment and a sense of competition and appreciation; this is used for the realization of external goals (Akbaba, 2006; Amabile, 1983).

Keller (1983) developed the ARCS (Attention, Relevance, Confidence and Satisfaction) model after analysing various research studies on motivation (Akbaba, 2006). The attention dimension in the model emphasizes the importance of the student's attention to the lesson. The relevance dimension establishes the link between course content and the student's interests, needs and expectations. The confidence dimension includes the process of recognizing the necessary personal benefits of the student from the course and focusing on them. Finally, the satisfaction dimension is about how well the education meets the student's expectations. Keller (1983) suggests that motivation is an important variable for an effective instructional design and students can gain higher achievement if their motivation for learning is provided for (Acar, 2009; Sal1, 2002).

\section{Importance of Current Study}

It is possible to come across studies that propose solutions for the problems encountered in teaching programming (Bayman \& Mayer, 1983; Gomes \& Mendes, 2007; Kantaria et al., 2020; Kinnunen \& Malmi, 2008; Malik et al., 2020; Mhashi \& Alakeel, 2013; Nouri et al., 2019; Nordin, 2021; Tan et al., 2009; Van Merrienboer \& Paas, 1990). In many of these studies, the achievement and motivation of students learning programming were compared in terms of methods such as e-learning, m-learning, or game-based learning. However, there are a limited number of studies on the use of worked-examples and animation-based teaching methods in teaching programming and there are no studies on the use of these methods. The workedexamples method allows a student to follow the same path that an expert follows while working. In this way, it becomes easier to learn a difficult topic (Schunk, 2011). In addition, the animation-based teaching method makes the teaching interesting by drawing students' attention to the phenomenon they are learning and thus motivating them (Weiss, Knowlton \& Morrison, 2002).

The current study investigates the effect of using a mixed method combining both animationbased learning and worked-examples for teaching programming, which is accepted to be somewhat difficult and complex. In addition, the animations developed within the scope of this study were presented to students by using AR technology.

AR technology, which is one of the next generation technologies with stimulating features, allows one to present virtual information together with real learning materials in an interactive way. Therefore, students do not lose touch with the traditional working papers they are accustomed to and are not detached from their usual learning environment and materials.

\section{Aim of this Study}

The aim of the current study is to examine the effects of instructional materials including Animation-based Worked Examples presented with AR technology in teaching programming 
on the academic achievement, attitudes, and motivation of students. Thus, the following three research questions will be investigated:

(1) Is there a significant difference in the students' academic achievement while learning through Animation-based Worked Examples (ARAWE) and Traditional Worked Examples (TWE)?

(2) Does the motivation of students who are learning through ARAWE and TWE:

(a) have a meaningful difference in terms of the "Attention-Relevance" submotivation dimension?

(b) have a meaningful difference in terms of the "Confidence-Satisfaction" submotivation dimension?

(3) Is there an association between achievement and attitude levels of students using ARAWE?

\section{Method}

A non-equivalent control group design from quasi-experimental models was used in the research. This model was preferred as the students were assigned to either the control or experimental groups.

\section{Participants}

The participants consisted of second year students $(\mathrm{N}=94)$ who were taking the "Basics of Programming" course in the Department of Information Technologies at a vocational and technical Anatolian high school in Turkey. The Quota Sampling method is a non-probability sampling method where the researcher defines a quota for each group and as s/he reaches the number defined, s/he performs random sampling (Altunışık et al, 2005; Erişti et al., 2013). Demographics related to the participants are given in Table 1.

Table 1. Demographics of participants in study.

\begin{tabular}{lllll}
\hline & \multicolumn{2}{l}{ Experimental Group } & Control Group & \\
\hline Gender & Male & Female & Male & Female \\
& 32 & 15 & 24 & 23 \\
TOTAL & 47 & & 47 & \\
\hline
\end{tabular}

\section{Data Collection Tools and Material}

The following tools were used for data collection in the study.

\section{Achievement Test}

An achievement test on the subject of the "For" loop in the "Basics of Programming" course was developed to be used as pre-test and post-test. The Cronbach Alpha calculated for the achievement test was .96. This test was applied as a pre-test prior to the application and as a post-test after the application.

The achievement test used in the study was developed specifically for the topic "For loop" of the course "basics of programming" and developed by following the steps in Figure 1. Two sample questions (Q) of the developed achievement test are as follows (translated from Turkish); 
Q1 (15 points): Write the statements of "for loop" that calculate the sum of the numbers between 10 and 50.

Q2 (15 points): Below are the program codes written from the keyboard as a number entered from the keyboard. Explain why "for-loop" is used to solve this problem.

Console.Write ("Enter the text:");

String myText $=$ Console $\cdot \operatorname{ReadLine}()$;

Console.Write("number :");

int myNumber $=$ Convert .ToInt32(Console . ReadLine ()$)$;

for (int $\mathrm{i}=1 ; \mathrm{i}<=$ myNumber; $\mathrm{i}++$ )

\{

ConsoleWriteLine(myText);

\} 


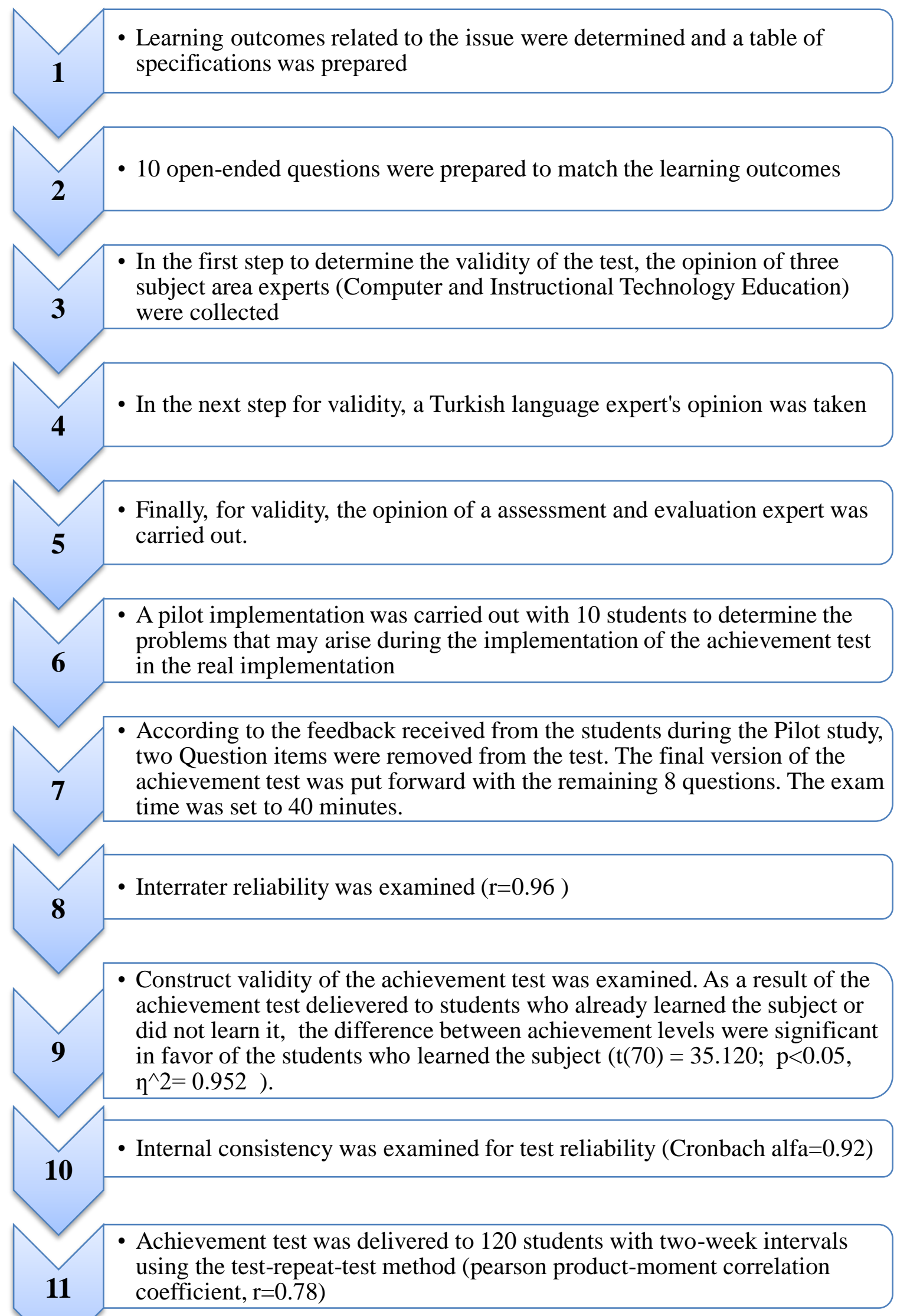

Figure 1. Development stages of the Achievement Test. 


\section{Motivation Scale}

To measure how students are motivated by the instructional materials, the "Instructional Materials Motivation Survey" (IMMS) developed by Keller (1983) was used. Kutu and Sözbilir (2011) adapted this survey into Turkish. The original scale consists of four-dimensions (attention, relevance, confidence, satisfaction) and 36 items. The survey applied to a total of 262 students by Kutu and Sözbilir (2011) was designed in two dimensions, "AttentionRelevance" and "Confidence-Satisfaction" and included 24 items (Cronbach Alpha=0.83). There are 19 positive and 5 negative items in the survey.

\section{AR Applications Attitude Scale}

The Augmented Reality Applications Attitude Scale (ARAAS) prepared by Küçük et al. (2014b) was applied in order to measure the students' attitudes towards AR (Augmented Reality), since the students were learning via instructional materials prepared with AR technology (Cronbach Alpha= 0.83). This Likert scale consisted of 15 items in total, 9 positive and 6 negative items. The sub-dimensions of ARAAS are "the use satisfaction", "the use anxiety", and "the use willingness". The "the use satisfaction" measures the satisfaction level of students regarding the use of AR applications; "the use anxiety" dimension measures the anxiety level of students while they are using AR applications, and "the use willingness" measures the willingness level of students to use AR in the future (Küçük et al., 2014b).

\section{ARAWE and TWE Materials}

Within the scope of this study, two different teaching materials were developed to teach the "for-loop" subject, one of the basics in teaching programming. The animations of the teaching materials were prepared in the Microsoft PowerPoint program. The animations created were converted to video format and spoken by a voice-over specialist. The Augmented Reality software used in the presentation of these animations was VUFORIA and UNITY.

The paper based TWE material was developed using the worked examples method. The subject content in the TWE material was equated with the ARAWE material. Finally, the TWE material was converted to pdf file format. Thus, two teaching materials were prepared with the same subject content and narration method, but different presentation styles (TWE and ARAWE).

In the study, ARAWE (Figure 3) for the experimental group and TWE material (Figure 2) for the control group were designed to teach students the subject "For" loop in Basic Programming. Both materials were prepared in the form of worked examples. The required explanations about the examples were given in small letters and alphabetical order to the students in the TWE material (Figure 2). ARAWE material was prepared with AR-based animation technology. Here, explanations about the examples in the TWE materials were presented to the students step by step in the form of animations. In addition, narrators were also used in these animations (Figure 3). 
Sample 1: Write the "for loop" statements that display the counter values between 1 and 3 on the screen.

Answer:

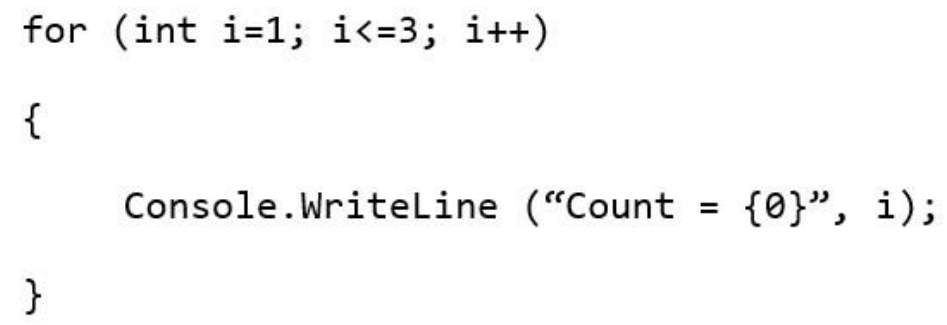

Step-by-Step Explanations on the Solution

Step 1

Start
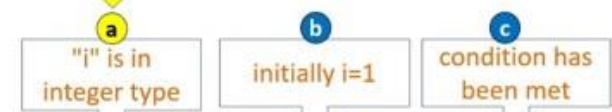

for ( int $\mathrm{i}=1$

\{

Console.Writeline("Count $=\{0\}$ ", i); \} (1) (1)
Explanations for Step 1

a At the begining of the "for loop" statement, the variable "i" is assigned to integer type,

b Initially, the variable "i" was assigned the value " 1 ".

C The $\mathrm{i}<=3$ condition was tested. The specified condition has been met.

d Entered the loop.

e With the help of the Console. WriteLine statement, "Count=1" is written to the console. f Value of variable " $\mathrm{i}$ " increased by 1 .

Figure 2. Text-based description of the problem's first step solution in TWE material. 


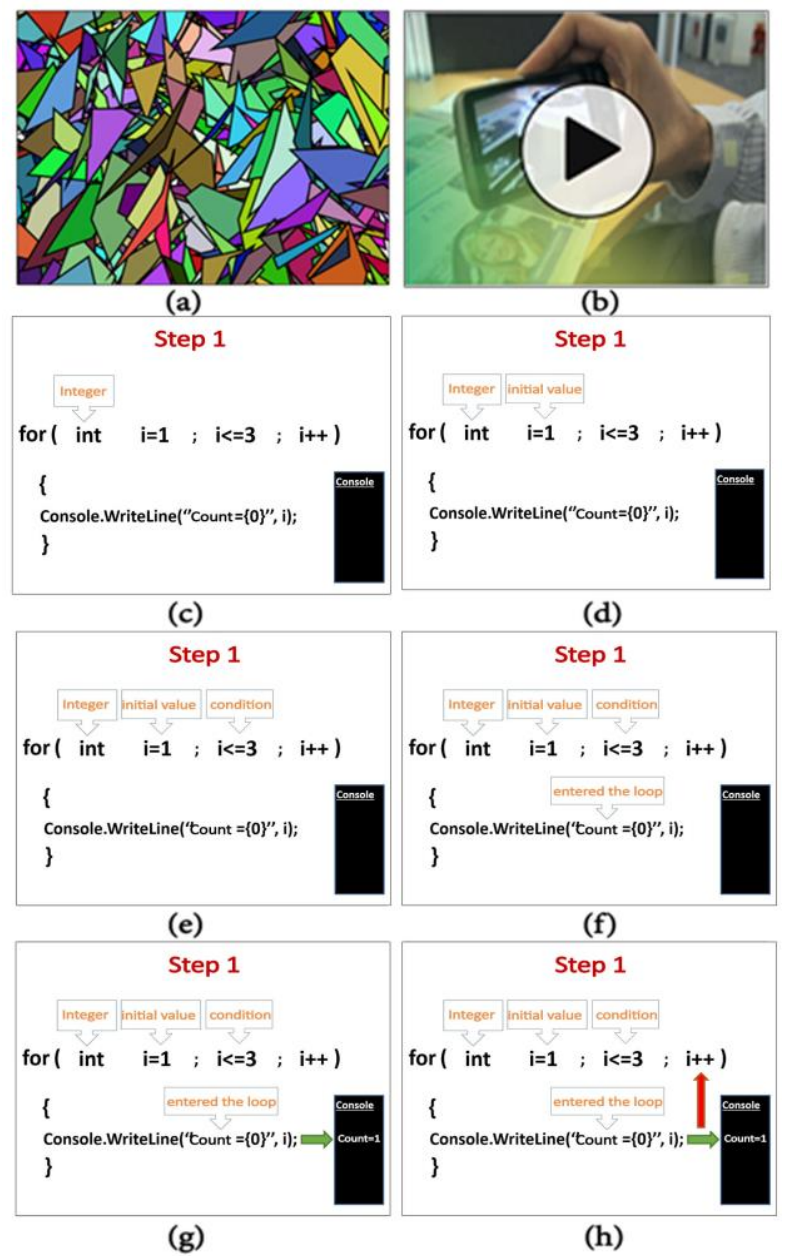

Figure 3. Sample animation visuals of the problem's first step solution in ARAWE material. (a) A marker that enables the display of AR-based animations by mobile devices, (b) Animation player, and (c, d, e, f, g, h) sample images proceeding with narrator's voice.

\section{Data Analysis}

In analysis of the quantitative data of the research, the SPSS program was used to obtain the arithmetic mean, standard deviation, and t-tests. As the pre-test scores did not indicate normal distribution, a Mann-Whitney $U$ test was performed. After the implementation, an independent sample t-test was run to compare the academic achievement and motivation subdimension scores of the groups. The correlation between the sub-dimensions of ARAAS and the post-test scores of each group were examined by calculating Pearson Correlation Coefficients.

\section{Procedure}

The experimental group students all had smartphones which could run AR applications. All these students were supplied with a headphone so that they did not disturb each other while listening to the narrative explanations in ARAWE (Figure 4). The application, which lasted for two weeks, was conducted in two different classrooms. The intervention was conducted in the second week. The experimental group students studied the subject for three hours with ARAWE material while the control group students studied the subject with TWE material (Figure 4). 

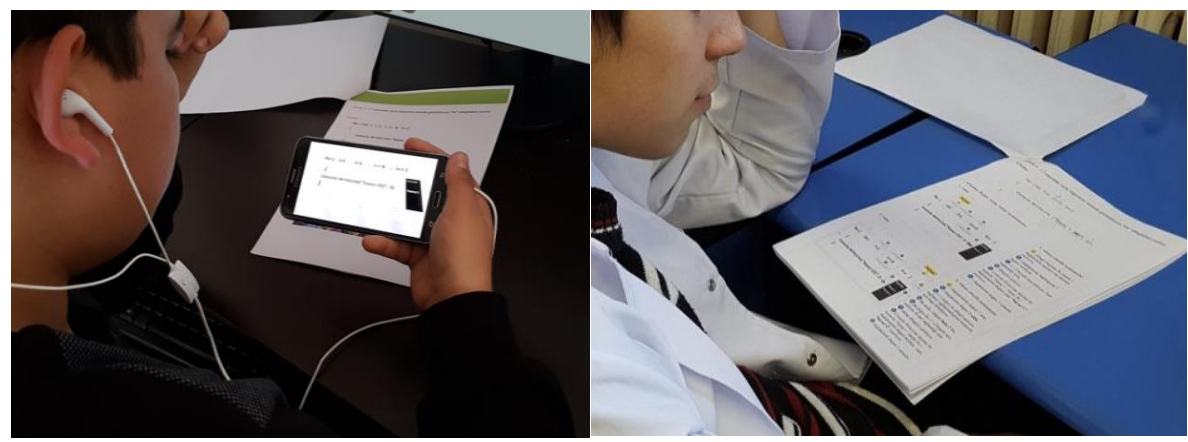

Figure 4. Student studying with ARAWE (left) and TWE (right).

At the end of the three-hour intervention, students were allowed to rest for 10 minutes, then a post-test was conducted to determine their achievement levels within a period of 40 minutes. Later, an IMMS survey was conducted. In addition, the AR Applications Attitude Scale was delivered to determine the AR attitude levels of the experimental group students. All interventions in both groups lasted for 20 minutes. The research design is indicated in Figure 5 .

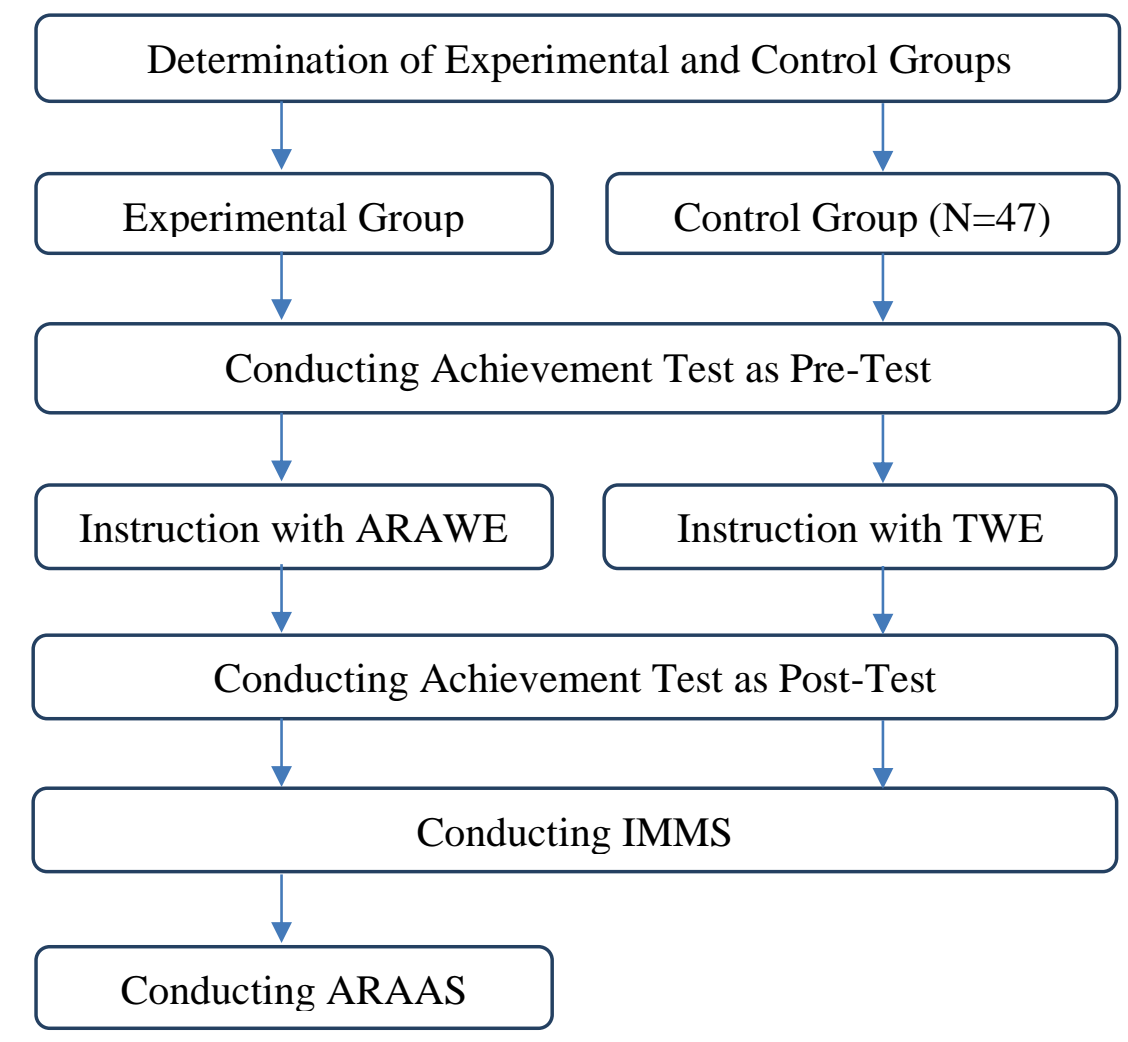

Figure 5. Data Collection Timeline.

\section{Results}

A pre-test was implemented to measure the achievement levels of the experimental and control group students in the first week. As the pre-test scores did not indicate a normal distribution, Mann-Whitney $U$ test was conducted. No statistical difference was found according to the pre-test scores of both groups of students $(U=1091.50, \mathrm{z}=-0.103, \mathrm{p}>0.05)$. 
Thus, it could be said that all students had the same pre-knowledge regarding the subject to be learned before the intervention.

\section{Correlation Between Post-Test Scores of Students Studying with ARAWE and TWE}

An independent sample t-test was implemented to measure the difference between the post-test scores of the students regarding their achievement after using ARAWE and TWE. The t-test results are shown in Table 2.

Table 2. Comparison of post-test results of experimental group (using AWARE) and control group (using TWE).

\begin{tabular}{llllllll}
\hline Post-test & Group & N & M & SD & t & df & p \\
\hline \multirow{2}{*}{ Achievement Test } & ARAWE & 47 & 69.1915 & 11.03480 & 24.398 & 92 & 0.000 \\
& TWE & 47 & 20.9787 & 7.85878 & & & \\
\hline
\end{tabular}

After analysis, a significant difference was found between the post-test scores of students learning with ARAWE and TWE (t0.05; $\left.92=24.398 ; \mathrm{p}<0.05 ; \eta^{2}=0,852\right)$. According to the results, post-test scores of the students using ARAWE (X=69.19) were found to be higher than the post-test scores of the students using TWE $(X=20.98)$. It may be said that the use of ARAWE made a positive effect on students' academic achievement.

\section{Comparison of Motivation Levels of Students Studying with ARAWE and TWE}

At first, it was considered to apply a one-way MANOVA test to determine whether there was a difference between the sub-dimensions of the survey measuring students' levels of motivation while learning through ARAWE and TWE. However, the "multiple linear correlation" and "variance equality" conditions required to perform this test were violated. For this reason, data regarding the sub-dimensions of the motivation survey were analyzed with a t-test.

\section{Comparison of Motivation of Students Using ARAWE and TWE Materials in context of "Attention-Relevance" Sub-Motivation Dimension}

After the intervention, an independent sample t-test was implemented to determine whether there was a difference between the scores of the "Attention-Relevance" sub-motivation dimension of the students studying through ARAWE and TWE. The results are indicated in Table 3.

Table 3. T-Test Results of "Attention \&Relevance" Levels of Motivation.

\begin{tabular}{|c|c|c|c|c|c|c|c|c|}
\hline $\begin{array}{l}\text { Motivation } \\
\text { Dimension }\end{array}$ & Sub- & Group & $\mathbf{N}$ & $\mathbf{M}$ & SD & $\mathbf{t}$ & df & $\mathbf{p}$ \\
\hline Attention & & ARAWE & 47 & 4.1373 & 0.41002 & 23.005 & 84.365 & 0.000 \\
\hline \&Relevance & & TWE & 47 & 2.4313 & 0.30060 & & & \\
\hline
\end{tabular}

After analysis, a significant difference was found ( $\mathrm{t} 0.05 ; 84.365=23.005 ; \mathrm{p}<0.05 ; \eta^{2}=0,852$ ) in favor of the students studying through ARAWE compared to TWE regarding the "AttentionRelevance" sub-dimension of motivation. 


\section{Comparison of Motivations of Students Using ARAWE and TWE Materials in context of "Confidence-Satisfaction" Sub-Motivation Dimension}

After the intervention, an independent sample t-test was implemented to determine whether there was a difference between the scores of the "Confidence-Satisfaction" submotivation dimension of the students studying through ARAWE and TWE. The results are indicated in Table 4.

Table 4. T-Test Results of "Confidence \&Satisfaction" Levels of Motivation.

\begin{tabular}{|c|c|c|c|c|c|c|c|c|}
\hline $\begin{array}{l}\text { Motivation } \\
\text { Dimension }\end{array}$ & Sub- & Group & $\mathbf{N}$ & M & SD & $\mathbf{t}$ & df & $\mathbf{p}$ \\
\hline Confidence & & ARAWE & 47 & 4.2471 & 0.19771 & 41.093 & 86.454 & 0.000 \\
\hline \&Satisfaction & & TWE & 47 & 2.3077 & 0.25613 & & & \\
\hline
\end{tabular}

After the analysis, a significant difference was found (t0.05; $86.454=41.093 ; \mathrm{p}<0.05 ; \eta^{2}=$ 0,95 ) in favor of the students studying through ARAWE compared to TWE regarding the "Confidence-Satisfaction" sub-dimension of motivation.

\section{Correlation Between Post-Test Scores of Students Studying through ARAWE and their Level of Attitudes toward AR Technology}

The correlation between the post-test scores of the students and the ARAAS subdimensions ("the use satisfaction", "the use anxiety", "the use willingness") were examined by calculating with Pearson Correlation Coefficients (Field, 2009). The correlation values between the post-test scores of the students studying through ARAWE and their attitudes toward the AR are indicated in Table 5.

Table 5. Correlation Between post-test Scores of Students Studying through ARAWE and their Level of Attitudes toward AR Technology.

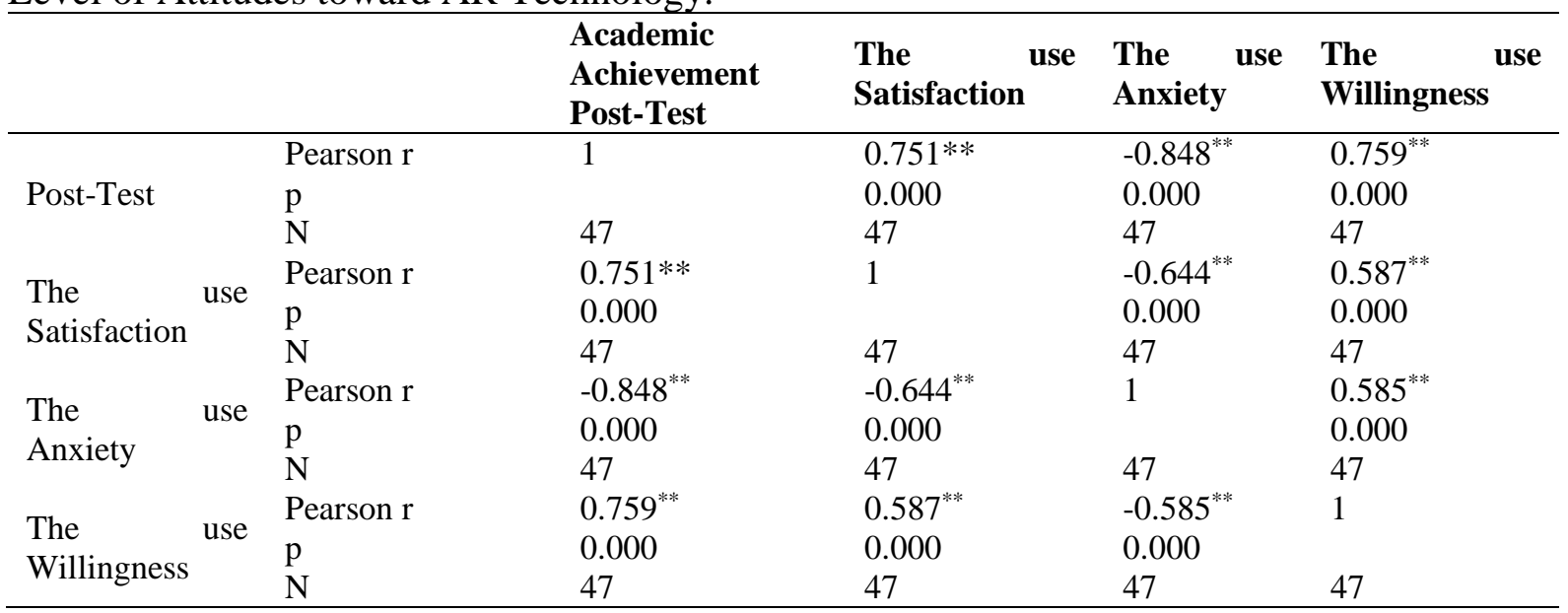

According to Cohen (1988), if this correlation is between 0.10-0.29, there is a low correlation, if it is between 0.30-0.49, there is a medium correlation, and if it is between 0.5-1, there is a strong correlation between the two variables. Thus, as can be seen from Table 5, a positive and a high level of correlation was found between the post-test scores of the students studying through ARAWE. The score for the motivation sub-dimension of "the use satisfaction" is $(0.5<\mathrm{r}<1 ; \mathrm{p}<0.05)$ and "the use willingness" score is $(0.5<\mathrm{r}<1 ; \mathrm{p}<0.05)$ concerning attitudes towards AR. However, a negative and high level of correlation was found between the post-test scores of students studying through ARAWE and the scores for the motivation sub-dimension of "the use anxiety" $(0.5<|\mathrm{r}|<1 ; \mathrm{p}<0.05)$ regarding attitudes towards AR. 
The Power Values (r2) for the correlations between the post-test scores of the students studying through ARAWE and their attitudes toward AR are indicated in Table 6.

Table 6. Power Values for Correlations.

\begin{tabular}{lllllll}
\hline & Power & Post-test & $\begin{array}{l}\text { The } \\
\text { Satisfaction }\end{array}$ & $\begin{array}{l}\text { The } \\
\text { Anxiety }\end{array}$ & $\begin{array}{l}\text { use } \\
\text { Willingness }\end{array}$ \\
\hline Post-test & $\mathrm{r}^{2}$ & 1 & 0.564 & 0.719 & 0.576 \\
The use Satisfaction & $\mathrm{r}^{2}$ & 0.564 & 1 & 0.414 & 0.344 \\
The use Anxiety & $\mathrm{r}^{2}$ & 0.719 & 0.414 & 1 & 0.342 \\
The use Willingness & $\mathrm{r}^{2}$ & 0.576 & 0.344 & 0.342 & 1 \\
\hline
\end{tabular}

According to Huck (2008), if the calculated power value (r2) is between 0.10 and 0.30 there is a low correlation, if it is between 0.30 and 0.50 there is a medium correlation, and if it is greater than 0.50 then there is a strong correlation. The power values indicated in Table 6 indicate that the correlations between the post-test scores of students studying through ARAWE and the scores for the sub-dimensions of "the use satisfaction", $(\mathrm{r} 2=0.564>0.50)$, "the use anxiety", $(\mathrm{r} 2=0.719>0.50)$ and "the willingness of use", $(\mathrm{r} 2=0.576>0.50)$ indicate that attitudes towards AR were strong.

\section{Discussion and Conclusion}

Developments in today's technology greatly influence the design of instructional materials and lead to the emergence of new teaching strategies, as well as techniques. In the present study, the effects of the use of animation-based worked examples which were implemented through AR technology on the academic achievement, motivation, and attitudes of high school students in teaching programming were investigated.

The use of animation prepared in accordance with the principles of Multimedia Design in educational materials facilitates the teaching of difficult topics (Sakman, 2020). In addition, animations help the elimination of learning difficulties by allowing students to embody and mentally animate abstract events and objects (Arıcı \& Dalkılıç, 2006).

When the literature is examined, it is recognized that programming involves many complex learning processes and is therefore a difficult skill to learn. In this context, there are several studies aimed at eliminating the difficulties experienced in teaching programming (Aissa et al., 2020; Bosse \& Gerosa, 2016; Cevahir \& Özdemir, 2017; Cheah, 2020). A study conducted by Cevahir and Ozdemir (2017) states that at the beginning, the factors that make learning programming difficult are deficiencies in analytical thinking, problem solving and mathematical thinking skills. In addition, programming tools, languages and writing rules are difficult to understand; in addition, the teaching methods that are used make learning programming difficult for students (Erümit et al., 2019). In this context, our study considered the advantages offered by AR-supported animations and the studied examples method for teaching. Furthermore, it was investigated whether these methods contribute to overcoming difficulties in teaching programming.

A significant difference was found in favour of students with ARAWE between the post-test scores of the students studying through ARAWE and the post-test scores of the students studying through TWE, stemming from the fact that the students who were exposed to 
animations in a step-by-step mode through ARAWE learnt better. This finding supports many studies in which the positive effects of animation use in programming education have been reported (Jawad et al., 2018; Matsuma \& Shindo, 2001; Rudder et al., 2007; Végh, 2016). It is also supported by the study carried out by Catrambone and Seay (2002) who reported that animations were effective at transferring information to long-term memory, which influenced the students' learning of computer algorithms positively.

Thus, it may be stated that animation-based materials facilitated students' learning of programming skills, which requires intensive cognitive processes and complex problemsolving. Similarly, according to Chiou, Tien, and Lee (2015), animation-based instruction had positive effects on achievement in problem-solving lessons such as maths, physics, and chemistry. Thus, it may also be stated that the high academic achievement of students who were studying through ARAWE may have stemmed from the use of animation. Another cause of this difference in the post-test scores could be explained by the fact that the students studying through TWE may have had difficulty matching the items on the left side of the screen with the ones on the right while reading the items in a step-by-step mode. Furthermore, the students' unwillingness to read the items on TWE may have affected their achievement adversely, which is related to their motivation. Supporting this, Guthrie and Wigfield (2000) stated that individuals with high motivation for reading use more cognitive strategies in understanding what they read than other individuals. The students endeavoured more to understand the stepby-step explanations while studying through TWE compared to those studying through ARAWE. It can be said that while the students who were studying through TWE probably had some problems reading and visualizing the subject in their minds, the students studying through ARAWE probably did not have such a problem due to the facilities it provided, which had a positive effect on their academic achievement. In addition, ARAWE which was developed with innovative technology, AR may have positively affected students' attention for learning and, consequently, their achievement.

When the relationship of the students studying through AWARE and TWE materials according to the sub-dimensions of the motivation scale were examined, it was observed that the students studying through ARAWE had higher motivation scores than the ones studying through TWE. Supporting this finding, Rosen (2009) stated that animation-based instruction in science and technology courses changed students' learning perceptions and affected their motivations positively. Sarı and Güven (2013) found in their study that learning with animations increased students' interest, attention and motivation in the lesson. When the related literature is examined, it is obvious that animation-based instruction has positive effects on student motivation (Chiou, Tien \& Lee, 2015; Rieber \& Kini, 1991; Rosen, 2009; Taşdemir, 2013; Tekdal, 2002). As a consequence, it may be stated that ARAWE material increases the motivation of students to learn basic programming compared to TWE material.

When the attitudes of the students regarding AR are examined, the results indicated a strong positive relationship between the academic achievement of students and their attitudes toward AR. That is, as students' academic achievement scores increased, there was also a positive increase in their attitudes toward AR. This relationship was also examined with regards to the sub-dimensions of "The Use Satisfaction", "The Use Anxiety" and "The Use Willingness". It was found that students" "The Use Satisfaction" toward ARAWE had a strong positive effect on their achievement. As the academic achievement of the students increased, the level of their satisfaction using the AR-based teaching material also increased.

When the "The Use Anxiety" sub-dimension of the attitude towards AR-based teaching 
material was examined, it was found out that the students' anxiety towards learning the subject significantly decreased. Therefore, we can infer that as the level of achievement of the students increases, their anxiety for studying through ARAWE material decreases.

When "The Use Willingness" sub-dimension of the attitude toward AR-based teaching material was examined, the students were found to have a medium level positive attitude toward the material. As the academic achievement of the students' increased, their willingness for using the AR-based teaching material also increased.

Overall, the positive correlation between the students' academic achievement and AR attitude levels may stem from their enthusiasm for using this innovative, attractive and entertaining learning environment with AR. Similarly, when Küçük, Y1lmaz, and Göktaş (2014a) examined the effect of using AR technology on the achievement, attitude, and cognitive load levels in teaching English as a foreign language, they found a positive relationship between the academic achievement of students and their attitude scores with AR technology. Sobrino et al. (2020) found that AR-supported learning material used as a teaching programming tool positively affects the motivation of the students. To recap, the current study focused on teaching the subject "for" loops of programming through the materials ARAWE and TWE. These materials can later be used for teaching other programming subjects and their effects on learning can be investigated by taking into account different measures. Considering that the instructional materials containing animation-based worked examples prepared using AR technology increase students' interest and motivation for the subject, their use in lessons that include teaching problem solving skills such as mathematics, physics, and chemistry can be implemented in future studies. As a consequence, considering the findings of the present study, the use of Animation-based and AR-based materials increases students' achievement and motivation as well as their having a more positive attitude. This indicates that their use in education may be promising for the future.

\section{Limitations of the research}

The findings from the study are limited to the data collected from sophomores who studied between 2015-2016 and 2016-2017 academic years in Mehmet Akif Ersoy Vocational and Technical Anatolian High School in Çanakkale. In addition, these findings are limited to the teaching of the subject "for loop" in the course "Basics of Programming".

\section{References}

Abdüsselam, M. S. (2014). Teachers' and students' views on using augmented reality environments in physics education: 11th grade magnetism topic example. Pegem Journal of Education and Instruction, 4(1), 59-74. https://doi.org/10.14527/pegegog.2014.004

Abdul-Rahman, S., \& Boulay, B. (2014). Learning programming via worked-examples: relation of learning styles to cognitive load. Computers in Human Behavior, 286-298. https://doi.org/10.1016/j.chb.2013.09.007

Acar, S. (2009). The effects of ARCS motivation strategies on learners academic successes permanences of learning, motivations and attitudes in web supported performance based (Doctoral dissertation). Ankara: Gazi University Educational Sciences Institute.

Adesope, O. O., \& Nesbit, J. C. (2013). Animated and static concept maps enhance learning from spoken narration. Learning and Instruction(27), 1-10. https://doi.org/10.1016/j.learninstruc.2013.02.002 
Aissa M., Al-Kalbani M., Al-Hatali S., BinTouq A. (2020) Novice learning programming languages in omani higher education institution (Nizwa University) issues, challenges and solutions. In: Al-Masri A., Al-Assaf Y. (eds) Sustainable Development and Social Responsibility - Volume 2. Advances in Science, Technology \& Innovation (IEREK Interdisciplinary Series for Sustainable Development). Springer, Cham. https://doi.org/10.1007/978-3-030-32902-0_18

Akbaba, S. (2006). Eğitimde motivasyon [motivation in education]. Journal of Kazım Karabekir Education Faculty (13), 343-361.

Altunışık, R., Coşkun, R., Bayraktaroğlu, S., \& Yıldırım, E. (2005). Sosyal bilimlerde arasstırma yöntemleri: SPSS uygulamall.[Research methods in social sciences: SPSS applied.] Sakarya: Sakarya Bookstore.

Amabile, T. M. (1983). Motivation and Creativity: Effects of motivational orientation creative writers. ERIC Document Reproduction. Service No: 240445.

Azuma, R. T. (1997). A survey of augmented reality. presence: teleoperators and virtual environments, 6(4), 355-385.https://doi.org/10.1162/pres.1997.6.4.355

Bacanll, H. (2003). Gelişim ve Ögrenme [Development and Learning]. Ankara: Nobel Publishing.

Bayman, P., \& Mayer, R. E. (1983). A diagnosis of begining programmers' misconceptions of BASIC programming statements. Comminications of the ACM, 26(9), 677-679.

Berney, S., \& Betrancourt, M. (2016). Does animation enhance learning? A meta-analysis. Computers \& Education (101), 150-167.

Betrancourt, M., \& Tversky, B. (2000). Effects of computer animation on user's performance: A review. Le Travail Humain, 63(4), 311-330.

Bosse, Y., \& Gerosa, M. A. (2016). Why is programming so difficult to learn?: patterns of difficulties related to programming learning mid-stage. ACM SIGSOFT Software Engineering Notes, 41(6), 1-6. https://doi.org/10.1145/3011286.3011301

Catrambone, R., \& Seay, A. F. (2002). Using animation to help students learn computer algoritms. Human Factors: The Journal of the Human Factors and Ergonomics Society 44(3), 495-511.https://doi.org/10.1518/0018720024497637

Cevahir, H., \& Özdemir, M. (2017). Teacher's opinions and suggestions for solutions towards challenges in teaching programming. 11. International Computer \& Instructional Technologies Symposium (s. 320-335). Malatya, Turkey: İnönü University.

Cheah, C. S. (2020). Factors contributing to the difficulties in teaching and learning of computer programming: a literature review. Contemporary Educational Technology, 12(2), 1-14. https://doi.org/10.30935/cedtech/8247

Chiou, C., Tien, L., \& Lee, L. (2015). Effects on learning of multimedia animation combined with multidimensional concept maps. Computers \& Education (80), 221223.https://doi.org/10.1016/j.compedu.2014.09.002

Cohen, J. (1988). Statistical power and analysis for the behavioral sciences (2 ed.). NJ: Lawrence Erlbaum Associates.

Collins, M. A., \& Amabile, T. M. (2007). Motivation and creativity. R. J. Sternberg in, Handbook of Creativity (s. 297-312). Newyork: Cambridge University Press.

Crippen, K. J., \& Earl, B. L. (2007). The impact of web-based worked examples and selfexplanation on performance, problem solving and self-efficacy. Computers \& Education, 49(3), 809-821.https://doi.org/10.1016/j.compedu.2005.11.018

Daşdemir, İ., \& Doymuş, K. (2016). The effect of using animation on primary science and technology course students' academic achivement, retention of knowledge and scientific process skills. Pegem Journal of Education and Instruction, 2(3), 33-42.

Erişti, S. D., Kuzu, A., Yurdakul, I. K., Akbulut, Y., \& Kurt, A. A. (2013). Scientific research methods. Eskişehir: Anadolu University. 
Ersoy, H., Duman, E., \& Öncü, S. (2016). Arttırılmış gerçeklik ile motivasyon ve başarı: deneysel bir çalışma [Motivation and success with augmented reality: an experimental study]. Journal of Instructional Technologies \& Teacher Education, 5(1), 39-44.

Erümit, K. A., Karal, H., Şahin, G., Aksoy, D. A., Gencan, A. A., \& Benzer, A. İ. (2019). a model suggested for teaching programming: programming in seven steps. Education and Science, 44(197), 155-183. http://dx.doi.org/10.15390/EB.2018.7678

Gomes, A., \& Mendes, A. J. (2007). Learning to program - difficulties and solutions. International Conference on Engineering Education - ICEE 2007, (s. 1-5). Coimbra, Portugal.

Fesakis, G., \& Serafeim, K. (2009). Influence of the familiarization with scratch on future teachers' opinions and attitudes about programming and ict in education. In proceedings of the 14th Annual ACM SIGCSE Conference on Innovation and Technology in Computer Science Education (ITiCSE-2009), 2, s. 258-262. Newyork, NY, USA.

Fidan, N. (1997). Okulda ögrenme ve ögrretme [Learning and teaching at school]. Ankara: Alkim Publishing House.

Field, A. P. (2009). Discovering statistics using SPSS third edition. Dubai: Oriental Press.

Freedman, M. P. (1997). Relationship among laboratory instruction, attitute toward science, and achievement science knowledge. Journal of Research in Science Teaching, 34(4), 343-357.

Guthrie, J. T., \& Wigfield, A. (2000). Engagement and motivation in reading. In M. L. Kamil, P. B. Mosenthal, P. D. Pearson, \& R. Barr, Handbook of Reading Research (3 ed., pp. 403-422). New York: Longman.

Hegarty, M., Kriz, S., \& Cate, C. (2003). The roles of mental animations and external animations in understanding mechanical systems. Cognition and Instruction, 21(4), 325-360.https://doi.org/10.1207/s1532690xci2104_1

Helminen, J., \& Malmi, L. (2010, October). Jype-a program visualization and programming exercise tool for Python. In Proceedings of the 5th international symposium on Software visualization (pp. 153-162). ACM. https://doi.org/10.1145/1879211.1879234

Hodhod, R., Fleenor, H., \& Nabi, S. (2014). Adaptive augmented reality serious game to foster problem solving skills. Workshop Proceedings of the 10Th International Conference on Intelligent Environments, (pp. 273-284). https://doi.org/10.3233/978-1-61499-411-4273

Höffler, T. N., \& Leutner, D. (2007). Instructional animation versus static pictures: a metaanalysis. Learning and Instruction, 17(6), 722-738. https://doi.org/10.1016/j.learninstruc.2007.09.013

Huck, S. W. (2008). Reading statistics and research (5th edition). Boston, USA: Allyn \& Bacon. ISBN:0205510671.

Ibáñez, M. B., Serio, Á., Villarán, D., \& Kloos, C. D. (2014). Experimenting with electromagnetism using augmented reality: impact on flow students experience and educational effectiveness. Computers \& Education, 71, 1-13. https://doi.org/10.1016/j.compedu.2013.09.004

Jawad, H. M., Tout, S., Abualkibash, M., \& Xie, Y. (2018). Integrating art and animation in teaching computer programming for high school students. (s. 311-317). Rochester, MI, USA: 2018 IEEE International Conference on Electro/Information Technology (EIT).

Kantaria, M., Basilaia, G., Dgebuadze, M., \& Chokhonelidze, G. (2020). Applying a new teaching methodology to university programming language courses. International Journal of Education and Research, 8(4), 33-44.

Keller, J. M. (1983). Motivational design of instruction. In C. M. Riegeluth, Instructional Design Theories and Models (pp. 386-434). Hillsdale: NJ: Lawrence Erlbaum. ISBN:0898592755. 
Kinnunen, P., \& Malmi, L. (2008). CS minors in a CS1 course. In Proceeding of The Fourth International Workshop on Computing Education Research, 06-07 September 2008. Newyork, USA: ACM.

Kirner, T. G., Reis, F. V., \& Kirner, C. (2012). Development of an interactive book with augmented reality for teaching and learning geometric shapes. Information Systems and Technologies, 1-6. https://doi.org/10.2190/ec.46.2.d

Kutu, H., \& Sözbilir, M. (2011). Adapting instructional materials motivation survey into Turkish: reliability and validity study. Necatibey Faculty of Education Electronic Journal of Science and Mathematics Education, 1(5), 292-312.

Küçük, S., Yılmaz, R. M., \& Göktaş, Y. (2014a). Augmented reality for learning english: achievement, attitude and cognitive load levels of students. Education and Science, 39(176), 393-404. https://doi.org/10.15390/eb.2014.3595

Küçük, S., Yılmaz, R. M., Baydaş, Ö., \& Göktaş, Y. (2014b). Augmented reality applications attitude scale in secondary schools: validity and reliability study. Education and Science, 39(176), 383-392.https://doi.org/10.15390/eb.2014.3590

Lahtinen, E., Ala-Mutka, K., \& Hannu-Matt, J. (2005). A study of the difficulties of novice programmers. Proceedings of the 10th Annual SIGCSE Conference on Innovation and Technology in Computer Science Education (s. 14-18). Caparia, Portugal: ACM Press.

Lin, T., Duh, H. B., Li, N., Wang, H., \& Tsai, C. (2013). An investigation of learners' collaborative knowledge construction performances and behavior patterns in an augmented reality simulation system. Computers \& Education, 68, 314-321. https://doi.org/10.1016/j.compedu.2013.05.011

Luzón, J. M., \& Letón, E. (2015). Use of animated text to improve the learning of basic mathematics. Computers \& Education(88), 119-128.

Malik, S. I., Al-Emran, M., Mathew, R., Tawafak, R. M., \& AlFarsi, G. (2020). Comparison of e-learning, m-learning and game-based learning in programming education. International Journal of Emerging Technology in Learning, 15(15), 133-146. https://doi.org/10.3991/ijet.v15i15.14503

Matsuda, H., \& Shindo, Y. (2001). Effect of using computer graphics animation in programming education. (s. 164-165). ICALT '01: Proceedings of the IEEE International Conference on Advanced Learning Technologies DOI Bookmark: https://doi.org/10.1109/ICALT.2001.943889

Ministry of Development [Kalkınma Bakanlığı]. (2015). 9. Strateji ve eylem planı. 20152018 bilgi toplumu stratejisi ve eylem planı [Strategy and action plan. 2015-2018 information society strategy and action]. Ankara: Ministry of Development

Mhashi, M. M., \& Alakeel, A. M. (2013). Difficulties facing students in learning computer programming skills at tabuk university. Recent Advances in Modern Educational Technologies (s. 15-24). Morioka City, Iwate, Japan: Proceeding of the 12th International Conference on Education and Educational Technology (EDU'13).

Moreno, R., \& Mayer, R. E. (2007). Interactive multimodal learning environments. Educational Psychology Review, 19(3), 309-326. https://doi.org/10.1007/s10648-007-9047-2

Morgan, T. C. (2005). Psikolojiye giriş [Introduction to psychology]. Ankara: Eğitim Bookstore Publishing.

Morrison, J. B., \& Tversky, B. (2001). The ineffectiveness of animation in instruction. Extended Abstract of the ACM Conference on Human Factors in Computing Systems, (s. 377378). Seattle: ACM.

Nouri, J., Zhang, L., Mannila, L., \& Norén, E. (2019). Development of computational thinking, digital competence and 21 st century skills when learning programming in K-9. Education Inquiry, 11(1), 1-17. 
Nordin, N. (2021). The effectiveness of online-based learning in java programming language: student perceptions and performance. Journal of Technology and Operations Management, 15(1), 1-24.

Önal, N. T., \& Söndür, D. G. (2017). I like technology usage in lessons and animations in science! The Journal of Academic Science Studies(55), 97-118.

Park, O. C., \& Gittelman, S. S. (1992). Selective use of animation and feedback in computerbased instruction. Educational Technology, Research, and Development(40), 27-38.

Rieber, L. P., \& Hannafin, M. J. (1988). Effects of textual and animated orienting activities and pratice on learning from computer-based instruction. Computers in the Schools(5), 7789.

Rieber, L. P. (1989). The effects of computer animated eleboration strategies and practice on factual and application learning in an elementary science lesson. Journal of Edcational Computing Research(5), 431-444.

Rieber, L. P., \& Kini, A. S. (1991). Theoretical foundations of instructional applications of computer-generated animated visuals. Journal of Computer-Based Instruction, 18(3), 83-88.

Rosen, Y. (2009). The effects of an animation-based on-line learning environment on transfer of knowledge and on motivation for science and technology learning. Journal of Educational Computing Research, 40(4), 451-467. https://doi.org/10.2190/ec.40.4.d

Rudder, A., Bernard, M., \& Mohammed, S. (2007). Teaching programming using visualization. WBED'07 Proceedings of the sixth conference on IASTED International Conference Web-Based Education, 2, s. 487-492.

Ryan, R., \& Deci, E. (2000). Instrictic and extrinsic motivations: classic definitions and new directions. Contemporary Educational Psychology(25), 54-67.

Sakman, S. (2020). Enriching multimedia learning materials with animation techniques. Fine Arts, 15(2), 116-126.

Salı, J. (2002). Uzaktan öğretimde güdüleyici öğrenme sistemlerinin tasarımı. [Design of motivational learning systems in distance education.] Açı ve Uzaktan Eğitim Sempozyити [Oral presentation presented at the International Open and Distance Education Symposium]. Eskişehir: Anadolu University Open Education Faculty.

Sarı, U., \& Güven, G. B. (2013). The effect of interactive whiteboard supported inquiry-based learning on achievement and motivation in physics and views of prospective teachers toward the instruction. Necatibey Faculty of Education Electronic Journal of Science \& Mathematics Education, 7(2), 110-143.http://dx.doi.org/10.12973/nefmed204

Sayın, Z., \& Seferoğlu, S. S. (2016). Yeni bir 21. yüzyıl becerisi olarak kodlama eğitimi ve kodlamanın eğitim politikalarına etkisi üzerine bir inceleme [A study on coding education as a new 21st century skill and the effect of coding on education policies]. Akademik Bilişim 2016 (s. 1-7). Aydın: Adnan Menderes University, 3-5 Şubat 2016.

Schunk, D. H. (1991). Self-efficacy and academic motivation. Educational Psychologist (26), 207-231.https://doi.org/10.1080/00461520.1991.9653133

Schunk, D. H. (2011). Learning theories and educational perspective. Pearson.

Sobrino, S. S., Vallejo, D., Morcillo, C. G., Redondo, M. A., \& Schez, J. C. (2020). RoboTIC: A serious game based on augmented reality for learning programming. Multimedia Tools and Applications (79), 34079-34099. https://doi.org/10.1007/s11042-020-09202$\mathrm{Z}$

Stebner, F., Kühl, T., Höffler, T. N., \& Wirth, J. (2017). The role of process information in narrations while learning with animations and static pictures. Computers \& Education(104), 34-48. http://dx.doi.org/10.1016/j.compedu.2016.11.001

Tan, P., Ting, C., \& Ling, S. (2009). Learning difficulties in programming courses: undergraduates' perspective and perception. 2009 International Conference on 
Computer Technology and Development (s. 42-46). IEEE Computer Society. https://doi.org/10.1109/ICCTD.2009.188

Taşkıran, A., Koral, E., \& Bozkurt, A. (2015). Artırılmış gerçeklik uygulamasının yabancı dil öğretiminde kullanılması [Using augmented reality application in foreign language teaching]. Academic Informatics 2015 (pp. 462-467). Eskişehir: Anadolu University, 4-6 February 2015.

Taşdemir, S. (2013). A general view to the motivation concept, motivation tools and for one model proposal information and communication technologies authority (Administrative thesis). Information and Communication Technologies Authority.

Tekdal, M. (2002). Etkileşimli fizik simüldaşasyonlarının geliştirilmesi ve etkin kullanılması [Development and effective use of interactive physics simulation]. V. National Science and Mathematics Education Congress. Ankara: ODTÜ.

Thompson, S. V., \& Riding, R. J. (1990). The effect of animated diagrams on the understanding of a mathematical demonstration in 11 to 14 year old pupils. British Journal of Educational Psychology(60), 93-98. https://doi.org/10.1111/j.20448279.1990.tb00925.x

Tversky, B., Bauer-Morrison, J., \& Betrancourt, M. (2002). Animation: can it facilitate? International Journal of Human-Computer Studies, 57(4), 247262.https://doi.org/10.1006/ijhc.2002.1017

Uluyol, Ç., \& Ery1lmaz, S. (2014). Examining pre-service teachers' opinions regarding to augmented reality. Gazi University Journal of Gazi Educational Faculty, 34(3), 403413. https://doi.org/10.17152/gefad.88379

Van Merrienboer, J. J., \& Paas, F. G. (1990). Automation and schema acquisition in learning elementary computer programming: implications for the design of practice. Computers in Human Behavior, 6, 273-289. https://psycnet.apa.org/doi/10.1016/07475632(90)90023-A

Végh, L. (2016). Javascript library for developing interactive micro-level animations for teaching and learning algorithms on one-dimensional arrays. Acta Didactica Napocensia, 9(2), 23-32.

Weiss, R. E., Knowlton, D. S., \& Morrison, G. R. (2002). Principles for using animation in computer-based instruction: Theoretical Heuristics for Effective Design. Computers in Human Behavior 18(4), 465-477. https://doi.org/10.1016/s0747-5632(01)00049-8

Wojciechowski, R., \& Cellary, W. (2013). Evaluation of learners' attitude toward learning in ARIES augmented reality environments. Computers \& Education, 68, 570-585. https://doi.org/10.1016/j.compedu.2013.02.014

Yıldız, M., Çiftçi, E., \& Karal, H. (2017). Bilişimsel düşünme ve programlama. Eğitim Teknolojileri Okumaları [Computational thinking and programming. Educational Technology Readings], TOJET

Zhi, R., Marwan, S., Dong, Y., Lytle, N., Price, T. W., \& Barnes, T. (2019a). Toward datadriven example feedback for novice programming. International Educational Data Mining Society, 218-227.

Zhi, R., Price, T. W., Marwan, S., Milliken, A., Barnes, T., \& Chi, M. (2019b). Exploring the impact of worked examples in a novice programming environment. SIGCSE '19: Proceedings of the 50th ACM Technical Symposium on Computer Science Education, (s. 98-104). https://doi.org/10.1145/3287324.3287385 